\title{
10
}

\section{Disrupting mainstream discourse in teacher education through decolonising pedagogies}

\author{
Sharon Subreenduth
}

\section{Introduction}

\begin{abstract}
s a transnational subject in the West with shifting positionalities Third World subject from South Africa now living in the United States - I use my teaching experiences as analytical possibility for legitimising transnational epistemologies within dominant educational discourse and theory-making in higher education settings. In contextualising myself within this chapter, I utilise Smith's use of transnational as 'shifting spaces' that recognise that the 'other is not located solely in the margins and distant places but is here and there, within and outside, visiting home as well as visiting the metropolitan institution' (2008:551). My shifting transnational spaces are located respectively within my experiences in US higher education settings and in SA as a western educated diasporic and subject of apartheid. This transnational theorising is actualised through the praxis of social justice and an analysis of the critical tensions in engaging with difference (ie identity, nationality, race and knowledge) within my courses.

While I utilise US higher education as a context of analysis, the decolonising pedagogies espoused here, rooted in global South experiences of colonialism and oppression, have implications for the approach of pre-service teacher training in the South as well. My hope for such transnational analysis is an alternative lens through which to examine the discursive nature of race, power and knowledge. I assert that my socio-political and educational ex-
\end{abstract}


periences in the South have offered me a more critical, complex and nuanced approach to dealing with issues of diversity and difference in the West (Subreenduth, 2008). This move challenges the colonial knowledge export model in which the West is always the producer of knowledge and the South always the recipient.

Globally, educational scholars (Smith, 1999; Rizvi, 2009; Gillborn, 2009; Fataar, 2010; Spivak, 1993) have discussed the need to make connections amongst indigenous, multicultural and local-global discourses on social justice to better understand contemporary issues such as poverty, oppression and religion. However, while many US teacher education courses may want to engage in critical dialogue about issues of difference, diversity, equity and social justice, they often find little space to do so, given how dialogue about difference in teacher education is so tightly framed by monolithic ideas of truth and reality (McLaren, 1988). Merryfield's (2000) study on how/why teachers are not being prepared to teach about diversity, equity and global connectedness underscores the gaps in teacher preparation and professional development programs across the US. As a result, mainstream thinking and approaches to diversity education are reproduced in various forms, often without any interruption (see Kumashiro, 2008).

While this gap remains, calls by critical educators (Giroux, 2005; LadsonBillings and Brown, 2008) have highlighted the shortfalls of teacher preparation to challenge students and teachers beyond their comfort level and beyond what they think they already know about issues of social justice in education. Kumashiro argues that teacher education needs to take an antioppressive approach to teaching about diversity, difference, equity and social justice, irrespective of whether it engages with local or global societies, politics, histories and people. Such approaches are more consistent with using higher education for the public good as a space for critical and transformative possibilities, as we consider what it means to learn and contribute in society with the other.

This chapter highlights the imperative to develop and implement more critically nuanced, reflexive and diverse pedagogies in teacher preparation and professional development programmes, so as to better equip educators to understand, develop and implement pedagogies in their classrooms that work towards decolonising education (see Rhee and Subreenduth, 2006; Subedi and Daza, 2008; Subreenduth, 2010). While decolonising and social justice theoretical frames may have originated as the result of different local experiences in the West and the South, and may play out differently given dif- 
ferent histories, politics and contexts, they are interwoven and work against oppression and marginalisation.

For the purposes of this chapter I frame pedagogical encounters within a US higher education context and look closely at undergraduate pre-service teacher education courses that focused on social studies pedagogy. As a means to consider possibilities for decolonising pedagogical encounters and looking at representation of the other through familiar and common sense realities of my white middle-class students, I borrow two key concepts from two social justice oriented scholars.

- Kevin Kumashiro's anti-oppressive stance with its focus on how repetition leads to normalisation and common sense

bell hooks' transgressive pedagogy, as a pedagogy of resistance to hegemonic knowledge production and consumption.

Kumashiro and hooks produce alternative conceptualisations that interrogate Eurocentric and dominant forms of knowledge that continue to sanction monolithic ideas of truth and reality. This chapter is a call for teacher education programmes to move beyond making information available, so they engage students in alternative, more critical perspectives, counter narratives and pedagogies on issues of difference, diversity, oppression and social justice. In order to rupture the underpinnings of oppression, one needs to counter and disrupt the operations of othering and objectification within classrooms.

\section{Tiptoeing around issues of diversity and race in teacher preparation}

This chapter draws on data and my engagement with undergraduate social studies teacher preparation courses I taught. While these courses are not characterised as 'diversity' courses per se, a significant amount of course materials and dialogue are included and were intended to serve as a counter hegemonic intervention to mainstream curricula. Expectations of methods courses rarely incorporate an interrogation of how student diversity and alternative knowledges and perspectives can produce a different classroom dynamic, and hence a different engagement with content and a new construction of knowledges. Critical perspectives of difference should be integrated across a programme and not relegated to one course (Gay, 2000). However, when students expect diverse perspectives in a diversity course but not in other courses, they may experience a kind of cognitive dissonance.

Inserting difference into my methods class - not just through my bodied self (African immigrant, black Third World woman of Asian descent) but also by 
my insistence that students wrestle with issues of diversity, racism, globalisation and multiculturalism via the ways they think, practice and choose - is covertly questioned by students. When white middle-class pre-service teachers earnestly profess that race, color and ethnicity 'does not matter' in the class because they 'don't see it', because each child is 'equal', how and where does one begin to disrupt this continued pattern of perceived antiracist blindness? Pollock (2004) refers to this as colourmuteness; it mutes the discourse on race and racial inequalities and thereby maintains the status quo. Claiming such a position seems to allow students to move beyond issues of race, ethnicity and diversity without questioning their own privileges and those that govern the process of schooling. While diversity issues have a legitimate space to occupy in courses, including in its title 'multicultural', 'race' or 'diversity', integrating the analysis of such issues in my methods class is often met with cynicism, disdain and agitation by students.

\section{Anti-oppressive approach to repetition in education/society}

Kumashiro (2000) reviews four approaches typically used in mainstream antioppressive education: education for the other; education about the other; education that is critical about privileging and othering; and education that changes students and societies. His paper outlines and critiques the limits and possibilities of these four approaches. His argument is to move beyond any one of the above approaches; to use them in concert; and to include marginalised theories and perspectives that they exclude. This chapter puts anti-oppressive approaches to work in educational theorising and teacher preparation.

Efforts to challenge oppression are not free of contradictions, ambiguities or complicities. Kumashiro (2003) notes that anti-oppressive approaches to teaching and researching operate in ways that challenge some forms of oppression while complying with others. This complicity by educators and students is not always intentional, visible or knowingly resistive of social change. Kumashiro (2003:45) explains:

One reason that a desire for social change can coincide with a resistance to social change is that some educational practices, perspectives, social relations, and identities remain unquestioned. In fact, people, often consider some practices and relationships to be part of what schools and society are supposed to be, and fail to recognise how the repetition of such practices and relations - how having to experience them again and again - can help to maintain the oppressive status quo of schools and society. 
This desire and resistance to social change is exemplified in recent instances of conflict on who gets included or excluded from the stalwart of US high school culture - the prom. The prom and school dance (the latter is the typical end of high school activity in most countries) have generally reinforced mainstream stereotypical and repetitive images of male and female roles and concretised ideas of race, sexuality and gender as well as socioeconomic privilege. There are, for example, certain expectations for dresses, tuxes, limos, dinners and expensive venues. Recently these expectations have been interrupted and challenged by openly gay students wanting to attend their prom as same sex couples. This interruption of common sense expectations instigated openly hostile resistance from administrators and community, which led to legal battles over school policy and issues of equity (Best, 2000) http://thinkprogress.org/politics/2010/03/23/88131/mcmillen-alter native-prom/).

Kumashiro (2008) premises that the basic repetition of mainstream narratives, images and discourse is what makes them so normal and why they become framed as common sense. These entrenched common sense notions are part of the reason why it is so difficult to disrupt or learn against these normalised views of reality. Learning against repetition is a long-term, conscious and often tedious process - a process that requires patience and a willingness to be open and vulnerable. The difficulty of unlearning repetition is demonstrated in the following anecdote.

During a discussion on stereotyping and its implications for us as educators, I gave one of my pre-service social studies classes (all white, mainly female students) a short article - Taking the Offensive Against Offensive Toys (Gordon, 2002) to read. It was meant to stimulate a discussion on the political implications of toys, especially the stereotyping by gender and race and exclusions of marginalised groups. The article described how a teacher and his young students visited a toy store and after analysing toys and their packaging came to the conclusion that certain toys were racist, sexist and exclusionary. Students in this article were encouraged to write to the manufacturer about their complaints. One such read: 'Your product ... is racist and sexist because your toys only have whites on the toy but no blacks.' Another stated: 'one of your products is very badly stereotyped of a Native American ...' I asked my preservice students to share their reactions to this reading: there was silence and uncomfortable shifting. I then went on to ask whether any of them had played with Barbie or GI Joe dolls and if we used this article and our other class readings on diversity, how would they now analyse these dolls for stereotyping, if at all. 
After some politically correct feedback, a white female student blurted out: 'I basically think whoever wrote this article had nothing better to do with their time!' She was adamant that there was no stereotyping with these dolls, and that she believed young children do not discriminate when they play with toys. Asked how she knew this, she shared a story from teaching Sunday school class. One of the white kids in her group, she said, loved playing with a black Barbie doll and when she asked the little girl why she liked it she said she liked black Barbie's tan! According to her this was a positive affirmation of a black person and indicated a lack of racism or discrimination. The black Barbie doll was given value and meaning by the commodity of its tan, not the possibilities of friendship it presented, it being a 'nice doll' or smart or pretty, or because of any cultural characteristics deemed positive. While I am not sure of the exact skin color of that particular Barbie, even a cursory look at African American Barbie dolls shows that most mimic the physical features of the white Barbie doll but in a darker tone.

$R A C E$ is a current project of the American Anthropological Association, while video project Girl Like Me explores the standards of beauty imposed upon black girls and how the repetitious learning of who/what (white skin) is beautiful becomes normalised and desired (see http:/ /www.understandin grace.org/ lived/video/index.html). These common sense commodified precepts of beauty play out in my students' analysis of the Barbie, in which they end up simply reminiscing about childhood play and not interrupting essentialised discourses of gender, race, ethnicity and beauty. Some students, like the one quoted, expressed anger that the course attempts to disrupt the repetition of their childhood memories of play and re-read them in more critical and less romanticised ways. I believe that despite resistance to this interrupted reminiscing, the students could use this experience to re-read their childhood memories and that student resistance to anti-oppressive pedagogy can mark that pedagogy as anti-oppressive.

\section{Engaged pedagogy}

hooks' educational theory - engaged pedagogy - has developed out of an interplay of anticolonial, critical and feminist pedagogies and provided an 'engaging and powerful standpoint ... for interrogating biases in curricula that reinscribe systems of domination while simultaneously providing new ways to teach diverse groups of students' (1994:10). She critiques the banking education approach and its ideology of maintaining the status quo. While hooks addresses the cultural reproduction of dominant and discriminatory elements in educational settings and society, her analysis moves beyond classism to embrace the complexity of racism and sexism. 
hooks' theorising of an engaged pedagogy is largely built upon her own educational experiences as a black student and educator. As a woman who encountered oppressive racism, sexism and classism, her experiences of marginality helped shape and articulate her educational pedagogy - a pedagogy fundamentally based on developing and nurturing critical consciousness in both teachers and students. hooks (1994) outlines her educational theory by recollecting her educational experiences in school and at college. The teachers, according to her, were enacting a 'revolutionary pedagogy of resistance' by nurturing the students' intellect to become scholars, thinkers and cultural workers; this was a 'counter-hegemonic act, a fundamental way to resist every strategy of white racist colonisation' (p2). hooks refers to this type of education as the 'practice of freedom' (p3) - that is, a 'way of teaching [so] that anyone can learn' (p13).

Engaged pedagogy provides students with multiple perspectives, allowing them to know themselves better and to live in the world more fully by reaching 'critical awareness and engagement' - the foundation of engaged pedagogy (p14). I have tried to offer these multiple perspectives to my students to engage them in critical awareness about the canonised realities they experience so they can critique, dialogue and reflect on their commonsense notions of reality. For such discussions I have deliberately chosen books my students would have encountered at home or school. I often give my students a couple of books to review and analyse for such stereotypes.

Building on the aforementioned student's response to Barbie I added a story about Barbie, titled Barbie: The Pyramid Adventure (Balducci, 1998). Barbie goes to Egypt to visit her friend Christie, an archeology student. While visiting the tomb Christie is helping excavate, Barbie gets lost, falls asleep and dreams of herself and Christie as princesses. The other book, Babar the King (De Bruhoff, 1963), sees Babar the elephant leave the jungle to visit the city and return determined to build an elephant kingdom so the elephants can live in a civilised world.

For this activity I specifically ask students to pay close attention to the pictures in the books and consider what messages they might propagate. For instance, according to my reading, the visuals depict hierarchical, racist, and colonial images. These included: Barbie seated on a chaise longue with Christie, an African American doll, seated at her foot; and in Babar the King, the animals dressed up and acting European in order to be civilised. The first image is decidedly reminiscent of the master/slave narrative while the second indicates dominant racial, political and cultural power dynamics. 
I have used these books for two classes during two different semesters. Students fail to recognise any of these visuals' troubling aspects. Their reactions to the texts and visuals remain largely in the realm of fondly reminiscing about their childhood play. This highlights the imperative to equip students with theoretical and conceptual frameworks and for us as educators to utilise pedagogical strategies that help them re-read and re-interpret materials in critical ways that go beyond their personal experiences.

Engaged pedagogy seeks more than to nurture a reflective and critical stance or to develop in students a level of prescribed literacy, professional skills and conformity to the status quo. It calls for a reconceptualisation of knowledge and for linking theory to practice. Possibly the greatest downfall of most of our teacher preparation courses is the lack of strong theoretical frameworks that are inclusive of decolonising theories (Daza, forthcoming). Another possible issue in teacher preparation is the mainstream, liberal, politically correct and multicultural push for having students read from their own experiences. This is couched as student-centered pedagogy, but students often do not have access to multiple theoretical perspectives from which to re-read their world in ways that interrogate their personal experiences. Hence it remains childhood reminiscing.

Teacher preparation and K-12 pedagogy, whether taking place in the South or West, needs to push students beyond their own realities and experiences by providing multiple perspectives and alternative theoretical frameworks from which to re-read their experiences, common sense realities and dominant Eurocentric and canonical forms of knowledge. Willinsky (1998), for example, highlights how the legacies of colonialism and imperialism continue to inform contemporary discussions on science, history, geography and race in education and thus have implications for the ways in which these are taught in K-12 classrooms. In her analysis of how the Middle East gets represented, Senoy offers insights into the powerful ways the media reinforce canonised notions of gender, physical appearance, race and religion, and argues that this 'media-based schooling about the world' (2010:40) concretises mainstream narratives. She challenges educators to explore strategies to teach social science curricula in ways that offer more critical readings of the media and the messages it embeds. Transgressive education, like Kumashiro's antioppressive approach of learning against repetition, intends to interrupt the familiar, the taken for granted. For example, will the same students view the Barbie and Babar visuals differently after a class that allows opportunities to deconstruct the master narrative? 


\section{Towards decolonising pedagogies}

I have utilised Kumashiro and hooks as an impetus to analyse the need for making difference part of the mainstream in teacher education programmes and as a means to consider how this discourse can counter the repetition so embedded in our everyday thinking, dialogue, interactions and discourse. On the discussion of possible interventions I propose a two-pronged approach to engage teacher educators in more critical and nuanced dialogue. The first is getting students to understand that 'worlding' (Spivak, 1985a; 1985b) happens, that there are different perspectives at the center and periphery (and even within each) and how those ideas are controlled then shape subjects and life. Secondly, once it is recognised that multiple ways shape truth and reality, there is then the active engagement with other perspectives - an infiltration into dominant discourses.

According to Spivak (1985a; 1985b) worlding speaks of ways in which colonised spaces were constructed and ushered into the world through the Eurocentric mentality and made to be sovereign and normalised. This can be used to read how the changing demographics in the US brings the global other into local spaces. She speaks of worlding as taking place in subtle ways. Her example is of how the presence of the British soldier in India rewrites/worlds the colonial space as an imperial space for the native Indian simply by his presence, which then dislodges any other discourses. Again, Spivak's (1985a) colonial analysis ironically speaks to the ways in which difference within the US - be it immigrant, native, foreigner, race, gender, sexuality, poverty - creates the othered subject and gets packaged in particular ways through societal, cultural and political policy and curricula that are seen as abnormal.

For educators even to think about decolonising pedagogy, they need to understand the centre's ability to map the contours of both the centre and the margin and the ways in which the centre controls the dialogue about difference (Spivak, 1993; Jackson and Mazzei, 2011). This is why a complex, nuanced engagement and dialogue about issues of difference, diversity and equity are often marginalised as too ideological, controversial or irrelevant to local experiences. More often, and especially in non-diverse environments like the one I work in, a mainstream politically correct engagement of these issues takes place, sometimes to such an extent that these issues become sanitised, isolated or remain the purview of the other. Case studies and readings about poverty, difference and diversity in teacher education programmes are not enough to engage educators in decolonising pedagogies. This argument is supported by Kumashiro, who states: 'changing oppression requires disruptive knowledge not just more knowledge' (2000:10). Said (1993) 
referred to this disruptive knowledge as contrapuntal perspectives. These are perspectives and theoretical frameworks, often by the marginalised, that challenge and reinterpret dominant narratives in order to produce decolonising readings of our world and our interactions with it (see Subedi, 2010).

This is the decolonising scholarship of hope that Fataar (2010) and others advance. Fataar argues that:

A scholarship of hope ought to be based on bringing understandings of excluded communities and their perspectives and knowledges to academic consciousness. Such a scholarship is also meant to inform the critical pedagogical work of educators in school classrooms and university lecture halls. $(p 1)$

Should this scholarship of hope not be the impetus to serve the public good intentions of schooling, not just in South Africa but in the US too? Kumashiro, hooks, Spivak and Fataar challenge us to work against the familiar, the common sense, the taken for granted. Only when we move beyond these and subject our everyday normalised realities to an anti-oppressive, social justice analytic lens do we recognise and engage at a more conscious and critical level with the other. Through these concerted efforts, I see the work of decolonising pedagogy being realised.

As our local environments become increasingly implicated in global operations via our material, technological or cultural consumptions, we need carefully to rethink and rearticulate the global-local implications of difference, diversity, race, social justice and oppression. Educators, irrespective of geography, history, politics, can enable a more nuanced and complex understanding of social justice through disrupting canonised discourses and knowledge production and consumption. Such an approach will provide forums that challenge them to pay attention to ideological, imperial and personal curricular decisions. For educators like me, with socio-political lived experiences of the South and now practising and living in the West, this examination of how purposeful educator preparation programmes could offer spaces to challenge dominant curricula provides insights into how to generate productive possibilities for our students. This offers a space to also examine ways in which individuals and groups of people within the same geographic and othered locations construct, challenge, negotiate and interpret the political, cultural and historical aspects of their lived experiences.

While the dominant imagination of curriculum knowledge and power is always present in interactions, the possibilities presented in this chapter offer insights into the process by which educators can re-imagine, re-concep- 
tualise and disrupt dominant ways of knowing and consequently of teaching about oppression and social injustice. Such purposeful pedagogical experiences challenge educators to create curriculum knowledge that is more critically presented to their students. These interactions also remind us that teachers serve not just one role in the learning process but many. Like learners, their pre-existing attitudes and past experiences will colour the learning process, making it far from neat and homogenous. Thus schooling and learning opportunities must be sensitive to difference and account for externalities in the learning process. In offering my pre-service education students opportunities to re-examine themselves within the convoluted terrain of their course material, I also hope that engagement will yield more critical educators who become cognisant of the complexity of culture, race, politics, difference, diversity, social justice and anti-oppressive perspectives (Ayers et al, 2010).

Author note: I thank Stephanie Daza and Jeong-eun Rhee for their critical feedback on this chapter.

\section{References}

Ayers, W, Kumashiro, K, Meiners, E, Quinn, T, Stovall, D (eds) (2010) Teaching Towards Democracy: teachers as agents of change. Paradigm Publishers

Balducci, R (1998) Barbie: the pyramid adventure. USA: Grolier Books.

Best, A (2000) Prom Night: youth, schools, and popular culture. Great Britain: Routledge

Daza, S (forthcoming) Teaching the taboo: Including sexual orientation in teacher preparation courses. In P Jenlink (ed) Sexual Orientation and Teacher Identity: professionalism and LGBT politics in teacher preparation and practice. Lanham, MD: Rowman and Littlefield Publishers

De Bruhoff, J (1963) Babar the King. USA: Random House Inc

Fataar, A (2010) A defamiliarising scholarship of hope: a youth subjectivity and schooling perspective. South African Journal of Higher Education 25(1)

Gay, G (2000) Culturally Responsive Teaching: theory, research, and practice. New York: Teachers College Press

Gillborn, D (2009) Globalisation and social justice in education. In Ayers, W, Quinn T and Stovall D (eds ) Handbook of Social Justice in Education. New York: Routledge

Giroux, H (2005) Border Crossings: cultural workers and the politics of education. New York: Routledge

Gordon, L (2002) Taking the offensive against offensive toys. In Rethinking our Classrooms: teaching for equity and justice. Milwaukee: Rethinking Schools Publication

hooks, b (1994) Teaching to Transgress: education as the practice of freedom. New York: Routledge http://thinkprogress.org/politics/2010/03/23/88131/mcmillen-alternative-prom/:Lesbian Constance McMillen excluded from alternative prom organised by students' parents. (accessed August 2011) http://www.understandingrace.org/lived/video/index.html). RACE is a project of the American Anthropological Association (accessed August 2011)

Jackson, A and Mazzei, L (2011) Thinking with marginality. In A Jackson, L Mazzei (eds) Thinking with Theory in Qualitative Research: data across multiple perspectives. London: Routledge

Kumashiro, K (2000) Toward a theory of anti-oppressive education. Review of Educational Research 70(1) 25-53 
HIGHER EDUCATION FOR THE PUBLIC GOOD: VIEWS FROM THE SOUTH

Kumashiro, K (2003) Against repetition: addressing resistance to anti-oppressive change in the practices of learning, teaching, supervising, and researching. In A Howell and F Tuitt (eds) Race and Higher Education: rethinking pedagogy in diverse college classrooms. Harvard: Harvard Education Review Reprint Series

Kumashiro, K (2004) Against Common Sense: teaching and learning towards social justice. NY: RoutledgeFalmer

Kumashiro, K (2008) The Seduction of Common Sense: how the right has framed the debate on America's schools. New York: Teachers' College Press

Ladson Billings, G, and Brown, K(2008) Curriculum and cultural diversity. In F Connelly, M He and J Phillion (eds) The Sage Handbook of Curriculum and Instruction. Thousand Oakes, CA: Sage Publications

McLaren, P (1988) Foreword: critical theory and the meaning of hope. In H Giroux, Teachers as Intellectuals: toward a critical pedagogy of learning. New York: Bergin and Garvey

Merryfield, M (2000) Why aren't teachers being prepared to teach for diversity, equity, and global interconnectedness? A study of lived experiences in the making of multicultural and global educators. Teaching and Teacher Education 16 429-43

Pollock, M (2004) Colormute: race talk dilemmas in an American school. New Jersey: Princeton University Press

Rhee, J and Subreenduth, S (2006) (eds) Special issue: de/colonising education: Examining transnational localities. International Journal of Qualitative Studies in Education 19

Rizvi, F (2009) International perspectives on social justice in education. In W Ayers, T Quinn and D Stovall (eds) Handbook of Social Justice in Education. New York: Routledge

Said, E (1993) Culture and Imperialism. New York: Knopf

Senoy, O (2010) 'Ickity-Ackity open sesame': learning about the Middle East in images. In B Subedi (ed) Critical Global Perspectives: rethinking knowledge about global societies. NC: Information Age Publishing

Smith, L (1999) Decolonising Methodologies: research and indigenous people. London: Zed Books

Smith, $L$ (2008) On tricky ground: researching the native in the age of uncertainty. In N Denzin and Y Lincoln (eds) Handbook of Qualitative Research. Thousand Oaks, CA: Sage

Spivak, G (1985a) The rani of Simur. In F Barker (ed) Europe and its others Vol. 1 Proceedings of the Essex Conference on the Sociology of Literature. Colchester: University of Essex

Spivak, G (1985b) Three women's texts and a critique of imperialism. Critical Inquiry: Race, Writing, and Difference 12(1) 243-61

Spivak, G (1993) Outside in the Teaching Machine. New York: Routledge

Subedi, B and Daza, S (eds) (2008) The possibilities of postcolonial praxis in education. Race, Ethnicity and Education 11(1) 1-10

Subedi, B ed (2010) Critical Global Perspectives: rethinking knowledge about global societies. NC: Information Age Publishing

Subreenduth, S (2006) 'Why, why are we not even allowed...?': A de/colonising narrative of complicity and resistance in post-apartheid South Africa. International Journal of Qualitative Studies in Education 19(5) 617-38

Subreenduth, S (2008) Deconstructing the politics of a differently coloured transnational identity. Race, Ethnicity and Education 11(1) 41-55

Subreenduth, S (2010) Travel dialogues of/to the other: complicating identities and global pedagogy. In Subedi, B (ed) Critical Global Perspectives: rethinking knowledge about global societies. NC: Information Age Publishing

Willinsky, J (1998) Learning to Divide the World: education at empire's end. Minneapolis: University of Minnesota Press 